\title{
Disparate effects of $\mathrm{SO}_{2}$ on the selective catalytic reduction of $\mathrm{NO}$ by $\mathrm{C}_{2} \mathrm{H}_{5} \mathrm{OH}$ and IPA over $\mathrm{Ag} / \mathrm{Al}_{2} \mathrm{O}_{3}$
}

\author{
Qiang Wu, Qingcai Feng, Hong He * \\ State Key Laboratory of Environmental Chemistry and Ecotoxicology, Research Center for Eco-Environmental Sciences, \\ Chinese Academy of Sciences, Beijing 100085, China \\ Received 23 January 2006; received in revised form 9 February 2006; accepted 9 February 2006 \\ Available online 23 February 2006
}

\begin{abstract}
The selective catalytic reduction ( $\mathrm{SCR}$ ) of $\mathrm{NO}$ by $\mathrm{C}_{2} \mathrm{H}_{5} \mathrm{OH}$ and IPA (isopropyl alcohol) over $\mathrm{Ag} / \mathrm{Al}_{2} \mathrm{O}_{3}$ was studied in the presence of $\mathrm{SO}_{2}$. The results showed that $\mathrm{C}_{2} \mathrm{H}_{5} \mathrm{OH}$ performs much more effectively in the presence of $\mathrm{SO}_{2}$ compared with IPA. In situ DRIFTS study did not show the formation of sulfate species on $\mathrm{Ag} / \mathrm{Al}_{2} \mathrm{O}_{3}$, which might explain the high resistance of $\mathrm{Ag} / \mathrm{Al} \mathrm{O}_{3}$ to $\mathrm{SO} 2$ in the $\mathrm{SCR}$ of $\mathrm{NO}$ by $\mathrm{C}_{2} \mathrm{H}_{5} \mathrm{OH}$. In addition, the deactivation mechanism for the case using IPA as a reductant was also proposed based on the IR spectra results.
\end{abstract}

(C) 2006 Published by Elsevier B.V.

Keywords: In situ DRIFTS; Selective catalytic reduction; Sulfate species; Enolic species; Isocyanate species

\section{Introduction}

The SCR of NO by hydrocarbons or oxygen-containing organic compounds in the presence of oxygen over $\mathrm{Ag} / \mathrm{Al}_{2} \mathrm{O}_{3}$ has attracted much attention as a potential technology to remove NO from diesel and lean-burning engine exhaust [1-9]. However, the activity of $\mathrm{Ag} / \mathrm{Al}_{2} \mathrm{O}_{3}$ usually decreases in the presence of $\mathrm{SO}_{2}$ especially at lower temperatures, and the deactivation effect of $\mathrm{SO}_{2}$ is assigned to the formation of surface sulfate species on the catalyst $[10,11]$. From a practical point of view, the catalysts used for the SCR of NO should be resistant to inhibition by $\mathrm{SO}_{2}$ and $\mathrm{H}_{2} \mathrm{O}$ in real exhaust gases [1216]. Furthermore, the type of reductant is an important factor for the SCR of NO. Therefore, the development of more effective and inexpensive reductant in the presence of $\mathrm{SO}_{2}$ is also required for practical use.

To get more evidence for the sulphur-tolerant catalyst/ reductant, it is crucial to lay emphasis on investigating dif-

\footnotetext{
* Corresponding author. Tel.: +86 10 62849123; fax: +86 1062849123 . E-mail address: honghe@rcees.ac.cn (H. He).
}

ferent mechanisms of the SCR of NO in the presence of $\mathrm{SO}_{2}$. Since $\mathrm{C}_{2} \mathrm{H}_{5} \mathrm{OH}$ and IPA display the similar reducing capabilities in most cases, in this paper, we chose both as model reductants for the SCR of NO in the presence of $\mathrm{SO}_{2}$ to seek $\mathrm{SO}_{2}$ resistance system for industry utilization. We used in situ DRIFTS method to study the effect of $\mathrm{SO}_{2}$ on the formation of $\mathrm{NO}_{3}^{-}$, acetate $\left(\mathrm{CH}_{3} \mathrm{COO}^{-}\right)$, enolic species and isocyanate species $(-\mathrm{NCO})$, which are the key intermediates in the SCR of $\mathrm{NO}$ by $\mathrm{C}_{2} \mathrm{H}_{5} \mathrm{OH}$ or IPA. Through this study, we deduced the different mechanisms of the SCR of $\mathrm{NO}$ by these two reductants over $\mathrm{Ag} /$ $\mathrm{Al}_{2} \mathrm{O}_{3}$ in the presence of $\mathrm{SO}_{2}$.

\section{Experimental}

\subsection{Catalyst preparation}

$\mathrm{Ag} / \mathrm{Al}_{2} \mathrm{O}_{3}(5 \mathrm{wt} \%)$ catalyst was prepared by an impregnation method as following: $\mathrm{Al}_{2} \mathrm{O}_{3}$ powder $\left(200 \mathrm{~m}^{2} / \mathrm{g}\right)$ was dissolved in an appropriate amount of silver nitrate aqueous solution. The sample was dried at $393 \mathrm{~K}$ for $3 \mathrm{~h}$ and calcined at $873 \mathrm{~K}$ for $3 \mathrm{~h}$ in air. 


\subsection{Activity measurements}

The catalytic activity was measured in a fixed-bed reactor by passing a gaseous mixture of $\mathrm{NO}(800 \mathrm{ppm})$, reductant $\left(\mathrm{C}_{2} \mathrm{H}_{5} \mathrm{OH} 1565 \mathrm{ppm}\right.$, or IPA $\left.1043 \mathrm{ppm}\right), \mathrm{SO}_{2}$ (80 ppm), $\mathrm{O}_{2}(10 \%)$ in $\mathrm{N}_{2}$ balance at a total flow rate of $2000 \mathrm{~mL} / \mathrm{min}$ over $0.6 \mathrm{~g}$ catalyst $\left(W / F=0.018 \mathrm{~g} \mathrm{~s} \mathrm{~mL}^{-1}\right.$, $\left.\mathrm{GHSV}=\sim 50,000 \mathrm{~h}^{-1}\right)$. NO conversion was analyzed online by a chemiluminescence $\mathrm{NO} / \mathrm{NO}_{2} / \mathrm{NO}$ analyzer (42C-hl, Thermo Electron). An aqueous $\mathrm{C}_{2} \mathrm{H}_{5} \mathrm{OH}$ or IPA solution was supplied by a micro pump into the gas stream and vaporized by a coiled heater at the inlet of the reactor.

\subsection{In situ DRIFTS procedure}

In situ DRIFTS spectra were recorded on a NEXUS 670-FTIR equipped with a smart collector and a MCT/A detector cooled by liquid $\mathrm{N}_{2}$. The catalyst was finely ground and placed in a ceramic crucible. Prior to each experiment, the catalyst was firstly heated in a flow of $10 \mathrm{vol} \% \mathrm{O}_{2}+\mathrm{N}_{2}$ for $60 \mathrm{~min}$ at $873 \mathrm{~K}$, then cooled to the desired temperature, and a spectrum of the catalyst in the flow of $\mathrm{N}_{2}+\mathrm{O}_{2}$ serving as the background was recorded. All gas mixtures were fed at a flow rate of $300 \mathrm{~mL} / \mathrm{min}$. All spectra were measured with a resolution of $4 \mathrm{~cm}^{-1}$ and with an accumulation of 100 scans.

\section{Results and discussion}

\subsection{Reaction activity of $\mathrm{C}_{2} \mathrm{H}_{5} \mathrm{OH}$ and IPA for the SCR of} $\mathrm{NO}$ over $\mathrm{Ag} / \mathrm{Al}_{2} \mathrm{O}_{3}$ in the presence of $\mathrm{SO}_{2}$

The effect of $\mathrm{SO}_{2}$ addition to the feed gas mixture on the SCR activity over $\mathrm{Ag} / \mathrm{Al}_{2} \mathrm{O}_{3}$ was monitored as a function of time on stream at 673 and $723 \mathrm{~K}$, which corresponded to the temperatures for high NO conversions with $\mathrm{C}_{2} \mathrm{H}_{5} \mathrm{OH}$ and IPA. As indicated in Fig. 1, in the absence of $\mathrm{SO}_{2}$, a steady state $\mathrm{NO}$ conversion of $96.2 \%$ at $673 \mathrm{~K}$ was achieved in the first $2 \mathrm{~h}$ when using IPA as a reductant. Addition of $80 \mathrm{ppm} \mathrm{SO}_{2}$ to the feed gas dramatically decreased NO conversion from 96.2 to $13.2 \%$ in another $2 \mathrm{~h}$. Subsequently, a stable NO conversion was obtained for more than $6 \mathrm{~h}$. A similar decrease in the SCR activity occurred upon addition of $80 \mathrm{ppm} \mathrm{SO}_{2}$ to the feed gas at $723 \mathrm{~K}$ for IPA, but the activity decline stopped at $34.2 \%$ of $\mathrm{NO}$ conversion. This indicates that $\mathrm{SO}_{2}$ greatly deactivates the SCR activity of $\mathrm{Ag} / \mathrm{Al}_{2} \mathrm{O}_{3}$ when using IPA as a reductant, especially at low temperatures. In the case of $\mathrm{C}_{2} \mathrm{H}_{5} \mathrm{OH}$, the $\mathrm{NO}$ conversion was observed to increase slightly at short times and then pass a maximum to reach a stable level. The final NO conversion seemed to be slightly influenced by $\mathrm{SO}_{2}$. Such significant difference indicates that the reaction mechanism of the $\mathrm{SCR}$ of $\mathrm{NO}$ by $\mathrm{C}_{2} \mathrm{H}_{5} \mathrm{OH}$ in the presence of $\mathrm{SO}_{2}$ over $\mathrm{Ag} / \mathrm{Al}_{2} \mathrm{O}_{3}$ is different from that of using IPA as a reductant.

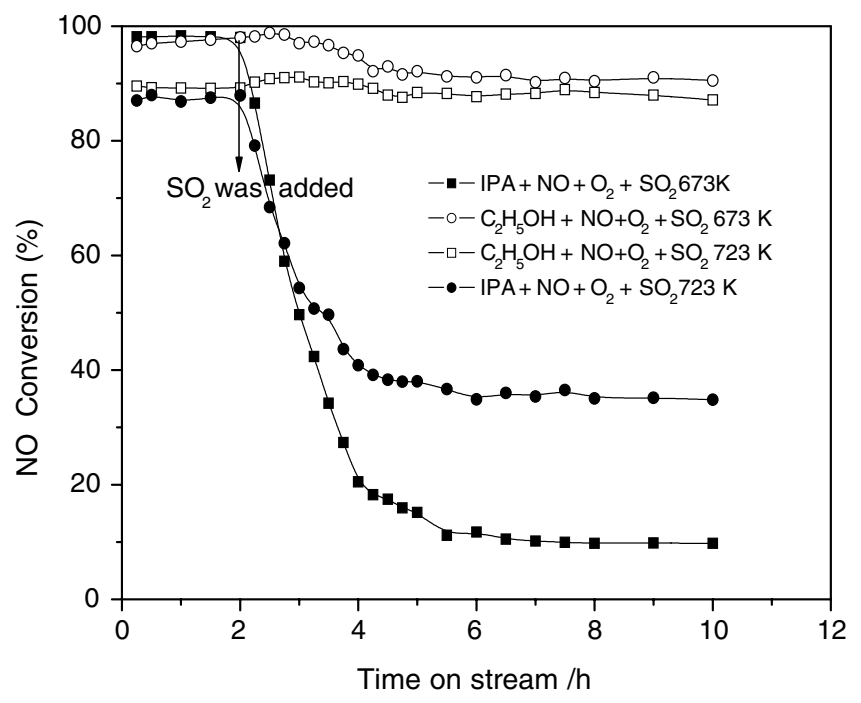

Fig. 1. Catalytic activity for $\mathrm{NO}$ reduction by $\mathrm{C}_{2} \mathrm{H}_{5} \mathrm{OH}$ and IPA over $\mathrm{Ag} /$ $\mathrm{Al}_{2} \mathrm{O}_{3}$ in the presence of $\mathrm{SO}_{2}$ at 673 and $723 \mathrm{~K}$. Conditions: $\mathrm{NO} 800 \mathrm{ppm}$, $\mathrm{C}_{2} \mathrm{H}_{5} \mathrm{OH} 1565 \mathrm{ppm}$ or IPA $1043 \mathrm{ppm}, \mathrm{O}_{2} 10 \%, \mathrm{SO}_{2} 80 \mathrm{ppm}, W /$ $F=0.018 \mathrm{~g} \mathrm{~s} \mathrm{~mL}^{-1}\left(\mathrm{GHSV}=\sim 50,000 \mathrm{~h}^{-1}\right), \mathrm{N}_{2}$ balance, total flow rate $2000 \mathrm{~mL} / \mathrm{min}$.

\subsection{Effect of $\mathrm{SO}_{2}$ on $\mathrm{Ag} / \mathrm{Al}_{2} \mathrm{O}_{3}$ for the $\mathrm{SCR}$ of $\mathrm{NO}$ by $\mathrm{C}_{2} \mathrm{H}_{5} \mathrm{OH}$ or IPA with in situ DRIFTS spectra}

The in situ DRIFTS spectra of $\mathrm{Ag} / \mathrm{Al}_{2} \mathrm{O}_{3}$ were recorded at various temperatures in steady states after exposing to $\mathrm{C}_{2} \mathrm{H}_{5} \mathrm{OH}+\mathrm{NO}+\mathrm{O}_{2}$ or to $\mathrm{IPA}+\mathrm{NO}+\mathrm{O}_{2}$. As shown in both Figs. $2 \mathrm{~A}$ and $2 \mathrm{~B}$, the very strong peak appeared at $2233 \mathrm{~cm}^{-1}$ is associated with the $-\mathrm{NCO}$ species, as observed in other $\mathrm{NO} / \mathrm{O}_{2} /$ hydrocarbons systems [7,17]. It has been widely accepted that - NCO species is a crucial intermediate in the SCR of $\mathrm{NO}$ over $\mathrm{Ag} / \mathrm{Al}_{2} \mathrm{O}_{3}$, and its high productivity results in a high efficiency of $\mathrm{NO}$ reduction. The peaks at 1633,1416 and $1336 \mathrm{~cm}^{-1}$ are assigned to the surface enolic species derived from the partial oxidation of $\mathrm{C}_{2} \mathrm{H}_{5} \mathrm{OH}$ or IPA over $\mathrm{Ag} / \mathrm{Al}_{2} \mathrm{O}_{3}\left(1633,1412\right.$ and $1338 \mathrm{~cm}^{-1}$ for IPA)

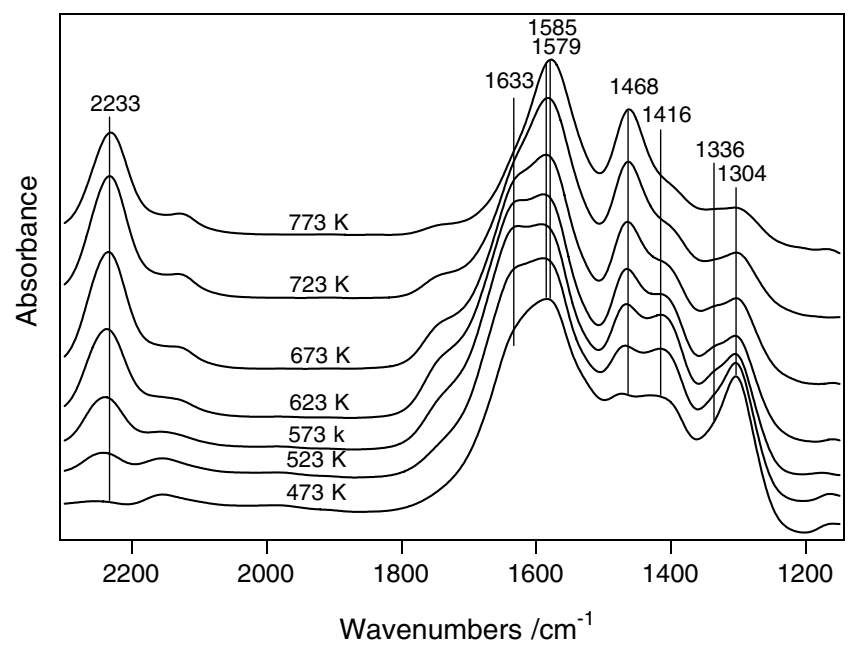

Fig. 2A. In situ DRIFTS spectra of adsorbed species on $\mathrm{Ag} / \mathrm{Al}_{2} \mathrm{O}_{3}$ in steady state at various temperatures in a flow of $\mathrm{C}_{2} \mathrm{H}_{5} \mathrm{OH}+\mathrm{O}_{2}+\mathrm{NO}$. Conditions: NO 800 ppm, $\mathrm{C}_{2} \mathrm{H}_{5} \mathrm{OH} 1565$ ppm, $\mathrm{O}_{2} 10 \%$. 


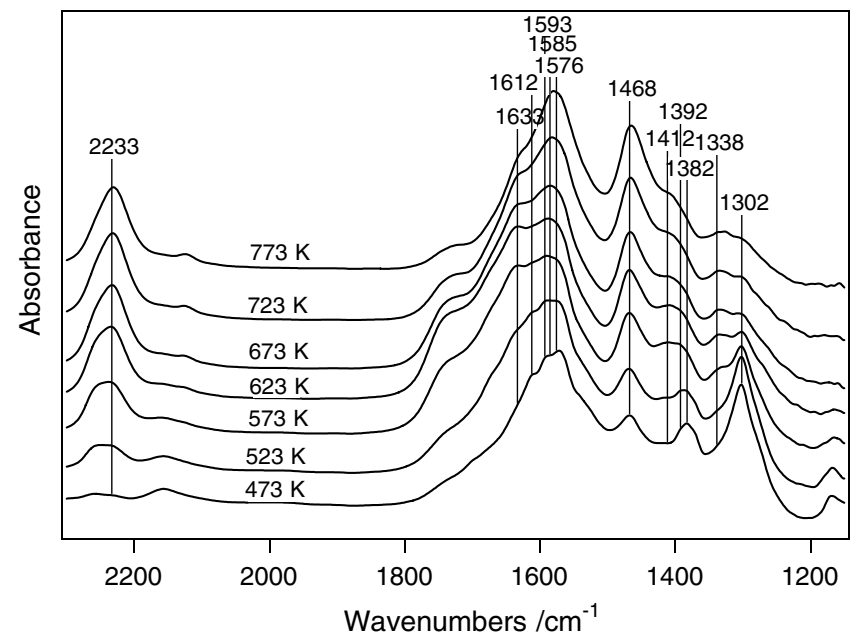

Fig. 2B. In situ DRIFTS spectra of adsorbed species on $\mathrm{Ag} / \mathrm{Al}_{2} \mathrm{O}_{3}$ in steady state at various temperatures in a flow of IPA $+\mathrm{O}_{2}+\mathrm{NO}$. Conditions: NO 800 ppm, IPA 1043 ppm, $\mathrm{O}_{2} 10 \%$.

$[18,19]$. The enolic species has been proved to play a crucial role in the $-\mathrm{NCO}$ species formation during the SCR of NO by $\mathrm{C}_{2} \mathrm{H}_{5} \mathrm{OH}$ or IPA. In addition, the peaks at 1579 (1576 for IPA) and $1468 \mathrm{~cm}^{-1}$ are assigned to the acetate species, the peaks at 1585 and $1304 \mathrm{~cm}^{-1}$ (1302 for IPA) are due to the adsorbed nitrates [7,19], and the peak at $1392 \mathrm{~cm}^{-1}$ in Fig. 2B can be associated with $\delta(\mathrm{C}-\mathrm{H})[18,20]$. We cannot observe the obvious difference between the two figures (Figs. $2 \mathrm{~A}$ and $2 \mathrm{~B}$ ), which is in a good agreement with the $\mathrm{Ag} / \mathrm{Al}_{2} \mathrm{O}_{3}$ activities for the SCR of $\mathrm{NO}$ with $\mathrm{C}_{2} \mathrm{H}_{5} \mathrm{OH}$ or IPA [19].

Figs. $3 \mathrm{~A}$ and $3 \mathrm{~B}$ show the spectra of $\mathrm{Ag} / \mathrm{Al}_{2} \mathrm{O}_{3}$ in the presence of $80 \mathrm{ppm} \mathrm{SO}_{2}$ in the flow of $\mathrm{NO}+\mathrm{C}_{2} \mathrm{H}_{5} \mathrm{OH}+$ $\mathrm{O}_{2}$ or $\mathrm{NO}+\mathrm{IPA}+\mathrm{O}_{2}$ at different temperatures, respectively. Comparing Figs. 2A with $3 \mathrm{~A}$, no obvious difference was observed between the two figures, that is, there was no sulfate species formed on $\mathrm{Ag} / \mathrm{Al}_{2} \mathrm{O}_{3}$. Therefore, we can conclude that co-existing $\mathrm{SO}_{2}$ hardly affects the $\mathrm{NO}$ reduc-

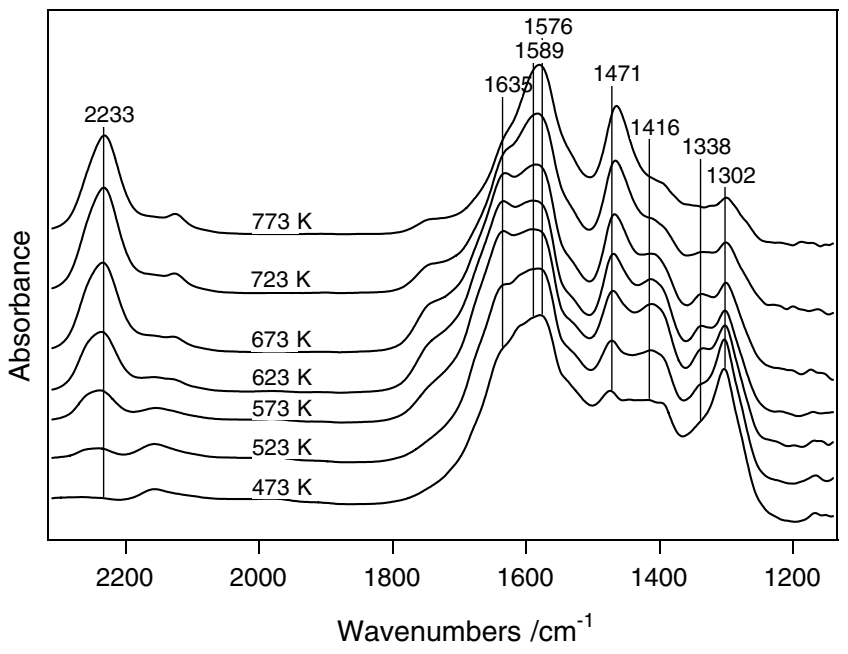

Fig. 3A. In situ DRIFTS spectra of adsorbed species on $\mathrm{Ag} / \mathrm{Al}_{2} \mathrm{O}_{3}$ at various temperatures in a flow of $\mathrm{C}_{2} \mathrm{H}_{5} \mathrm{OH}+\mathrm{O}_{2}+\mathrm{NO}+\mathrm{SO}_{2}$. Conditions: $\mathrm{NO} 800 \mathrm{ppm}, \mathrm{C}_{2} \mathrm{H}_{5} \mathrm{OH} 1565 \mathrm{ppm}, \mathrm{SO}_{2} 80 \mathrm{ppm}, \mathrm{O}_{2} 10 \%$.

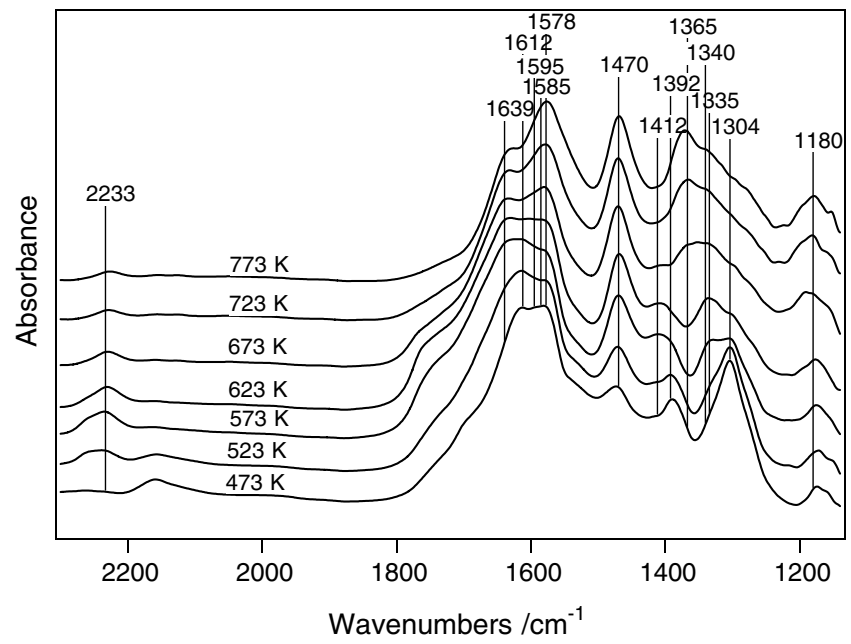

Fig. 3B. In situ DRIFTS spectra of adsorbed species on $\mathrm{Ag} / \mathrm{Al}_{2} \mathrm{O}_{3}$ at various temperatures in a flow of IPA $+\mathrm{O}_{2}+\mathrm{NO}+\mathrm{SO}_{2}$. Conditions: $\mathrm{NO}$ $800 \mathrm{ppm}$, IPA $1043 \mathrm{ppm}, \mathrm{SO}_{2} 80 \mathrm{ppm}, \mathrm{O}_{2} 10 \%$.

tion by $\mathrm{C}_{2} \mathrm{H}_{5} \mathrm{OH}$ over $\mathrm{Ag} / \mathrm{Al}_{2} \mathrm{O}_{3}$. This might explain the high efficiency of $\mathrm{NO}$ reduction by $\mathrm{C}_{2} \mathrm{H}_{5} \mathrm{OH}$ over $\mathrm{Ag} /$ $\mathrm{Al}_{2} \mathrm{O}_{3}$ in the presence of $\mathrm{SO}_{2}$, as confirmed by other experiments [4]. Comparing Figs. 2B with 3B, a most significant difference between the two figures was that a new broad peak appeared at $1340 \mathrm{~cm}^{-1}$ in Fig. 3B. Its intensity increased with the exposure time while its position shifted to $1365 \mathrm{~cm}^{-1}$, accompanied by another peak at $1180 \mathrm{~cm}^{-1}$ growing in intensity. According to the previous studies $[21,22]$, the peak at $1340 \mathrm{~cm}^{-1}$ could be observed and assigned to a surface sulfate species, while the peak at $1180 \mathrm{~cm}^{-1}$ could be assigned to a bulk sulfate species. However, our study using in situ DRIFTS and density functional theory (DFT) calculations has given new assignments for the two peaks, and the peaks at 1340 and $1180 \mathrm{~cm}^{-1}$ were attributed to asymmetric and symmetric stretching vibrations of (OSO) in bidentate sulfate species on $\mathrm{Ag} / \mathrm{Al}_{2} \mathrm{O}_{3}$, respectively. The second difference between Figs. $2 \mathrm{~B}$ and $3 \mathrm{~B}$ was that the intensity of the nitrates peak at $1304 \mathrm{~cm}^{-1}$ decreased promptly when the feed gas contains $80 \mathrm{ppm} \mathrm{SO}_{2}$. The third difference was that the NCO peak $\left(2233 \mathrm{~cm}^{-1}\right)$ also decreased dramatically in intensity. However, other peaks took little influence in intensity by the presence of $\mathrm{SO}_{2}$. Apparently, the presence of sulfate species blocked the formation of $\mathrm{NO}_{3}^{-}$, which can react easily with enolic species to form $-\mathrm{NCO}$ species. This led to the corresponding decrease in the SCR activity.

To further investigate the effect of $\mathrm{SO}_{2}$ on $\mathrm{Ag} / \mathrm{Al}_{2} \mathrm{O}_{3}$ in the flow of $\mathrm{NO}+\mathrm{C}_{2} \mathrm{H}_{5} \mathrm{OH}+\mathrm{O}_{2}$ or $\mathrm{NO}+\mathrm{IPA}+\mathrm{O}_{2}$, we also performed the in situ DRIFTS experiments as follows: when the reaction reaching a steady state at $60 \mathrm{~min}$, $80 \mathrm{ppm} \mathrm{SO}_{2}$ was introduced into the feed gas at $673 \mathrm{~K}$. The first two spectra in Figs. 4A and 4B were taken under $\mathrm{SO}_{2}$-free flow and other spectra were taken in the presence of $80 \mathrm{ppm} \mathrm{SO}_{2}$ at different time. Once again, we could not observe the presence of the sulfate species on $\mathrm{Ag} / \mathrm{Al}_{2} \mathrm{O}_{3}$ in Fig. 4A, indicating $\mathrm{NO}$ reduction by $\mathrm{C}_{2} \mathrm{H}_{5} \mathrm{OH}$ is not 
apparently affected by introducing $\mathrm{SO}_{2}$ into the feed gas. In contrast, in the case with IPA as a reductant in Fig. 4B, a new sulfate species peak also appeared at $1342 \mathrm{~cm}^{-1}$, with its intensity increased gradually and shifted to $1358 \mathrm{~cm}^{-1}$, along with another increasing peak appeared at $1178 \mathrm{~cm}^{-1}$, likewise the spectra in Fig. 3B. At the same time, both $-\mathrm{NCO}$ species peak $\left(2233 \mathrm{~cm}^{-1}\right)$ and nitrates peak $\left(1300 \mathrm{~cm}^{-1}\right)$ decreased promptly in intensity with the exposure time. The results again suggest that the formation of sulfates species on $\mathrm{Ag} / \mathrm{Al}_{2} \mathrm{O}_{3}$ not only inhibited the formation of $\mathrm{NO}_{3}^{-}$, but also suppressed the reaction of enolic species with $\mathrm{NO}_{3}^{-}$to form $-\mathrm{NCO}$ species. This should be responsible for the poor reduction of NO by IPA over $\mathrm{Ag}$ / $\mathrm{Al}_{2} \mathrm{O}_{3}$ in the presence of $\mathrm{SO}_{2}$.

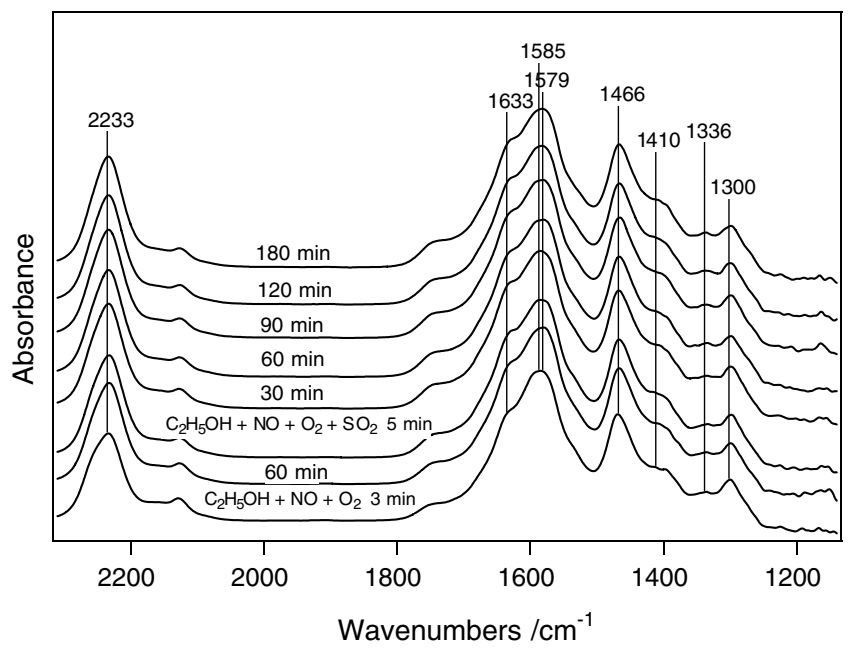

Fig. 4A. Changes of in situ DRIFTS spectra of adsorbed species on $\mathrm{Ag} /$ $\mathrm{Al}_{2} \mathrm{O}_{3}$ at $673 \mathrm{~K}$ in a flow of $\mathrm{C}_{2} \mathrm{H}_{5} \mathrm{OH}+\mathrm{O}_{2}+\mathrm{NO}+\mathrm{SO}_{2}$. Before the measurement, the catalyst was pre-exposed to a flow of $\mathrm{C}_{2} \mathrm{H}_{5} \mathrm{OH}+\mathrm{O}_{2}+\mathrm{NO}$ for $60 \mathrm{~min}$ at $673 \mathrm{~K}$. Conditions: $\mathrm{NO} 800 \mathrm{ppm}$, $\mathrm{C}_{2} \mathrm{H}_{5} \mathrm{OH} 1565$ ppm, $\mathrm{SO}_{2} 80 \mathrm{ppm}, \mathrm{O}_{2} 10 \%$.

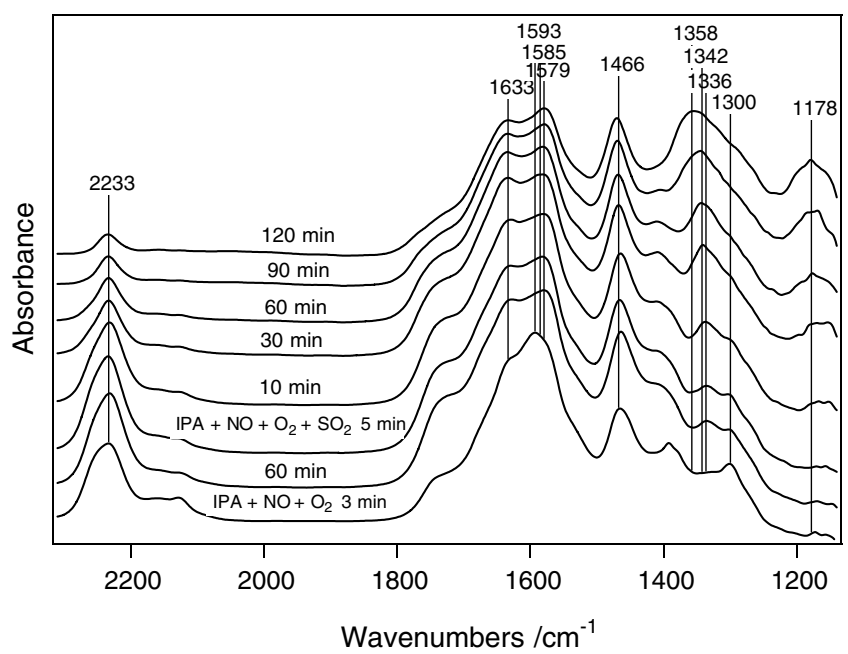

Fig. 4B. Changes of in situ DRIFTS spectra of adsorbed species on Ag/ $\mathrm{Al}_{2} \mathrm{O}_{3}$ at $673 \mathrm{~K}$ in a flow of IPA $+\mathrm{O}_{2}+\mathrm{NO}+\mathrm{SO}_{2}$. Before the measurement, the catalyst was pre-exposed to a flow of IPA $+\mathrm{O}_{2}+\mathrm{NO}$ for $60 \mathrm{~min}$ at $673 \mathrm{~K}$. Conditions: NO 800 ppm, IPA 1043 ppm, $\mathrm{SO}_{2} 80$ ppm, $\mathrm{O}_{2} 10 \%$.

\subsection{Mechanism analysis}

We have proposed a novel mechanism of the SCR of $\mathrm{NO}$ by $\mathrm{C}_{2} \mathrm{H}_{5} \mathrm{OH}$ or IPA over $\mathrm{Ag} / \mathrm{Al}_{2} \mathrm{O}_{3}$ [19]. It was shown that the enolic species, which are the main surface species during the partial oxidation of $\mathrm{C}_{2} \mathrm{H}_{5} \mathrm{OH}$ or IPA in the presence of oxygen, play a crucial role in the formation of $\mathrm{NCO}$ species by reacting with $\mathrm{NO}+\mathrm{O}_{2}$ or $\mathrm{NO}_{3}^{-}$on $\mathrm{Ag} /$ $\mathrm{Al}_{2} \mathrm{O}_{3}$. The formation of $-\mathrm{NCO}$ species is the rate-determining step in the SCR of $\mathrm{NO}$ by $\mathrm{C}_{2} \mathrm{H}_{5} \mathrm{OH}$ or IPA over $\mathrm{Ag} / \mathrm{Al}_{2} \mathrm{O}_{3}$. As can be seen from the in situ DRIFTS spectra (Fig. 4B), adding $80 \mathrm{ppm} \mathrm{SO}_{2}$ to the feed gas strongly inhibited the -NCO formation in the case of IPA, whereas $\mathrm{C}_{2} \mathrm{H}_{5} \mathrm{OH}$ took little influence (Fig. 4A). This was likely due to different kinds of enolic species formed from the partial oxidation of $\mathrm{C}_{2} \mathrm{H}_{5} \mathrm{OH}$ or IPA on $\mathrm{Ag} / \mathrm{Al}_{2} \mathrm{O}_{3}$. If the same enolic species were obtained during the partial oxidation of $\mathrm{C}_{2} \mathrm{H}_{5} \mathrm{OH}$ or IPA, significant difference in IR spectra between Figs. 3A and 3B (Figs. 4A and 4B) should not be expected. We assumed that the enolic species formed from the partial oxidation of $\mathrm{C}_{2} \mathrm{H}_{5} \mathrm{OH}$ contains two or four carbon atoms with high $\mathrm{SO}_{2}$ tolerance [18], while the enolic species derived from the partial oxidation of IPA contains three carbon atoms, which could not inhibit the formation of surface sulfate species on $\mathrm{Ag} / \mathrm{Al}_{2} \mathrm{O}_{3}$.

\section{Conclusions}

The SCR activity of NO reduction by IPA is significantly suppressed upon exposure of $\mathrm{Ag} / \mathrm{Al}_{2} \mathrm{O}_{3}$ to $80 \mathrm{ppm}$ $\mathrm{SO}_{2}$. In situ DRIFTS spectra indicated that the presence of sulfate species on $\mathrm{Ag} / \mathrm{Al}_{2} \mathrm{O}_{3}$ not only inhibits the formation of $\mathrm{NO}_{3}^{-}$, but also suppresses the reaction between enolic species and $\mathrm{NO}_{3}^{-}$to form $-\mathrm{NCO}$ species, which could account for the deactivation in the SCR of NO by IPA in the presence of $\mathrm{SO}_{2}$. In contrast, $\mathrm{C}_{2} \mathrm{H}_{5} \mathrm{OH}-\mathrm{SCR}$ of $\mathrm{NO}_{x}$ system has a high $\mathrm{SO}_{2}$ tolerance under the same experimental conditions. In situ DRIFTS spectra did not apparently show the formation of sulfate species on $\mathrm{Ag} /$ $\mathrm{Al}_{2} \mathrm{O}_{3}$ in the case of $\mathrm{C}_{2} \mathrm{H}_{5} \mathrm{OH}$. This probably explains the reason why $\mathrm{C}_{2} \mathrm{H}_{5} \mathrm{OH}$ is a more effective reductant than IPA in the SCR of $\mathrm{NO}$ over $\mathrm{Ag} / \mathrm{Al}_{2} \mathrm{O}_{3}$ in the presence of $\mathrm{SO}_{2}$.

\section{Acknowledgement}

This work was financially supported by the National Science Fund for Distinguished Young Scholars of China (20425722).

\section{References}

[1] T. Miyadera, Appl. Catal. B 2 (1993) 199.

[2] K.A. Bethke, H.H. Kung, J. Catal. 172 (1997) 93.

[3] S. Sumiya, H. He, A. Abe, N. Takezawa, K. Yoshida, J. Chem. Soc., Faraday Trans. 94 (1998) 2217.

[4] S. Sumiya, M. Saito, H. He, Q.-C. Feng, N. Takezawa, Catal. Lett. 50 (1998) 87. 
[5] T. Nakatsuji, R. Yasukawa, K. Tabata, K. Ueda, M. Niwa, Appl. Catal. B 17 (1998) 333.

[6] F.C. Meunier, J.P. Breen, V. Zuzaniuk, M. Olsson, J.R.H. Ross, J. Catal. 187 (1999) 493.

[7] S. Kameoka, Y. Ukisu, T. Miyadera, Phys. Chem. Chem. Phys. 2 (2000) 367.

[8] K. Shimizu, A. Satsuma, T. Hattori, Appl. Catal. B 25 (2000) 239.

[9] K. Shimizu, J. Shibata, H. Yoshida, A. Satsuma, T. Hattori, Appl. Catal. B 30 (2001) 151.

[10] F.C. Meunier, J.R.H. Ross, Appl. Catal. B 24 (2000) 23.

[11] N. Hickey, P. Fornasiero, J. Kaspar, M. Graziani, G. Martra, S. Coluccia, S. Biella, L. Prati, M. Rossi, J. Catal. 209 (2002) 271.

[12] E.A. Efthimiadis, S.C. Christoforou, A.A. Nikolopoulos, I.A. Vasalos, Appl. Catal. B 22 (1999) 91.

[13] F. Notoya, C. Su, E. Sasaoka, S. Nojima, Ind. Eng. Chem. Res. 40 (2001) 3732 .
[14] A. Abe, N. Aoyama, S. Sumiya, N. Kakuta, K. Yoshida, Catal. Lett. 51 (1998) 5.

[15] K. Sato, T. Yoshinari, Y. Kintaichi, M. Haneda, H. Hamada, Catal. Commun. 4 (2003) 315.

[16] G. Corro, A. Velasco, R. Montiel, Catal. Commun. 2 (2001) 369.

[17] Y. Ukisu, S. Sato, A. Abe, K. Yoshida, Appl. Catal. B 2 (1993) 147.

[18] Y. Yu, H. He, Q. Feng, H. Gao, X. Yang, Appl. Catal. B 49 (2004) 159.

[19] Q. Wu, H. He, Y. Yu, Appl. Catal. B 61 (2005) 107.

[20] N. Bion, J. Saussey, M. Haneda, M. Daturi, J. Catal. 217 (2003) 47.

[21] G. Centi, N. Passarini, S. Perathoner, A. Riva, Ind. Eng. Chem. Res. 31 (1992) 1947.

[22] M. Waqif, P. Bazin, O. Saur, J.C. Lavalley, G. Blanchard, O. Touret, Appl. Catal. B 11 (1997) 193. 